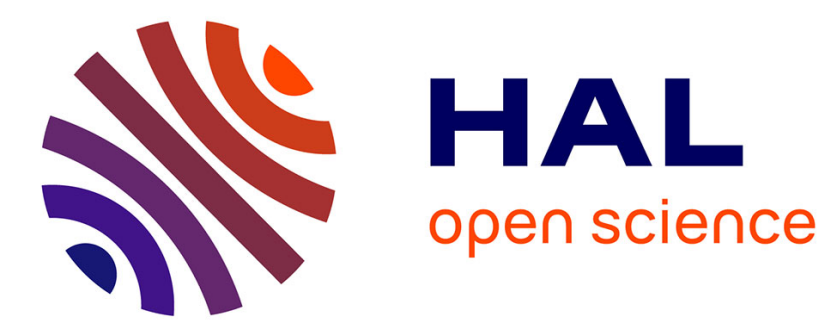

\title{
Spine virtual traumas under multiple impact situations
} Jingchao Sun, P Bertrand, R Kraenzler, Pierre-Jean Arnoux

\section{To cite this version:}

Jingchao Sun, P Bertrand, R Kraenzler, Pierre-Jean Arnoux. Spine virtual traumas under multiple impact situations. Computer Methods in Biomechanics and Biomedical Engineering, 2009, 12 (S1), pp.237-239. 10.1080/10255840903094050 . hal-00849246

\section{HAL Id: hal-00849246 \\ https://hal.science/hal-00849246}

Submitted on $30 \mathrm{Jul} 2013$

HAL is a multi-disciplinary open access archive for the deposit and dissemination of scientific research documents, whether they are published or not. The documents may come from teaching and research institutions in France or abroad, or from public or private research centers.
L'archive ouverte pluridisciplinaire HAL, est destinée au dépôt et à la diffusion de documents scientifiques de niveau recherche, publiés ou non, émanant des établissements d'enseignement et de recherche français ou étrangers, des laboratoires publics ou privés. 


\title{
Spine virtual traumas under multiple impact situations
}

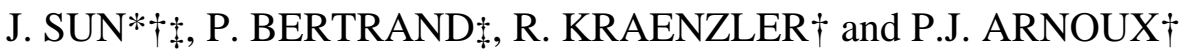 \\ † Laboratoire de Biomécanique Appliquée, UMRT24 INRETS Université de la Méditerranée, \\ Faculté de Médecine Nord, Bd. P. Dramard, 13916 Marseille cedex \\ ‡ SHARK-Helmets, Zac. De la valentine, 110 route de la Valentine, 13396 Marseille cedex 11 \\ *Corresponding author. Email: jingchao.sun@inrest.fr \\ Keywords: cervical spine; trauma; impact, finite element simulation
}

\section{Introduction}

The cervical spine segment is a very complex and mobile structure of the human body [1]. Once trauma situation occurs, the head-neck segment is highly loaded leading to severe trauma with a lethal or permanent incapacity risk. Cervical spine was largely studied from its mechanical properties to frontal impact to investigate whiplash mechanisms [2, 3]. For pedestrian, cyclist and motorcyclist accidents, the head-neck segment is loaded under various impact directions. Also, how these impact directions can have an incidence on the injury mechanisms, potential injury and their severity? To answer this question, the finite element simulation using existing dedicated models [4] could be a valuable tool. By simulating frontal, lateral, rear and oblique dynamic loadings on the HUMOS head-neck segment, a first numerical study showed weakness area on the spinal segment whatever the impact condition.

\section{Material and Methods}

The model used was the HUMOS head-neck segment under loading conditions relevant with those used for model validation [4]. For test convenience, the lower thorax, abdomen, lower and upper limb were removed. The upper thorax component was set as a rigid body and fixed. As no investigations were performed on head segment, it was set as rigid body. The test consisted in a $75 \mathrm{Kg}$ circular plate (to include whole body inertial effects) with an initial velocity of $5 \mathrm{~m} / \mathrm{s}$. Five loading conditions, from frontal impact to rear impact were investigated (cf. Figure 1). One major interest in human modelling remains in the possibility to record specific parameters which cannot be recorded during experiments. Hence, the numerical injury identifications are assessed through the combined analysis of the joints kinematics (to identify pathological movement [5]); the Von Mises level was assumed as an indicator for bone fracture (130MPa and 50MPa for compact and spongious bone respectively); and strain level to investigate potential failure risk for ligaments according to Yogonandan and Panjabi works [4, 6, 7]. Pressure level on intercervical disc was used as an indicator of the stress level in the structure.

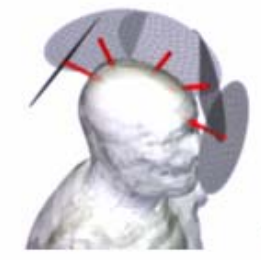

Figure 1 illustration of impact configuration 


\section{Results}

The frontal impact exhibits an extension kinematics. The lower cervical region i.e. around C4-6 was highly recruited leading to potential bone failure translating from C6 (20ms) to C5 (21ms) and C4 (33ms). The upper cervical component C0-C2 exhibits also a potential failure of the anterior longitudinal ligament (12.5ms) due to hyper extension effects.

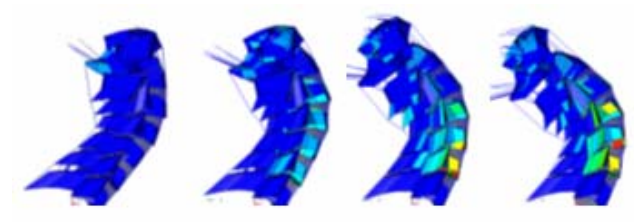

Figure 2 Von Mises for frontal impact

The lateral impact showed firstly potential bone fracture for the lower cervical spine structure with C6 bone fracture (6ms) to C5 (17ms) and C4 (21ms). Local rotation on C0-C2, induce potential failure of apical ligament (11.5ms).

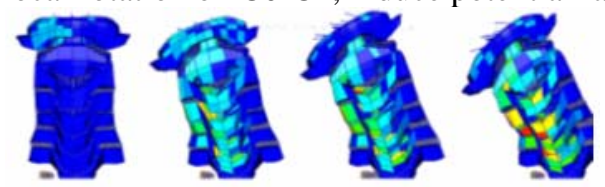

Figure 3 Von Mises for lateral impact

The rear impact showed that only ligaments injury induced by hyper flexion kinematics. The interspinous ligament (4ms) was assumed on C1-C2.

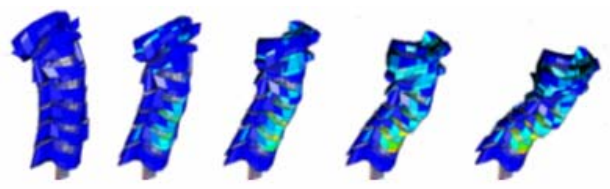

Figure 4 Von Mises for rear impact

The frontal oblique impact led to postulate on severe trauma probably induced by the combination of lateral and frontal extension. The lower cervical spine showed fractures from C6 (6ms) to C4 spine units. The ligament failures were postulated on the upper cervical spine mainly with apical ligament (10ms) on C0-C2.

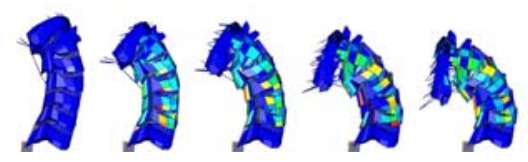

Figure 5 Von Mises for frontal oblique impact

The rear oblique impact exhibited the same combination effects as in the previous case: potential injury the interspinous ligament $(4.5 \mathrm{~ms})$ on $\mathrm{C} 0-\mathrm{C} 2$. Bone fracture seems to the rear impact with less severe compare to others impacts.

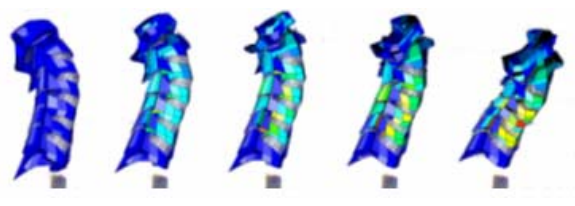

Figure 6 Von Mises for rear oblique impact 


\section{Conclusions - Discussion}

Simulations performed in these works exhibit potential injuries of the upper and the lower cervical spine. Bone fractures were essentially recorded from C6 to C4 in the frontal, lateral and frontal oblique impact simulations; the ligament injuries were most recorded on the upper cervical spine in the lateral, frontal oblique and rear oblique impact simulations. If the injury chronology showed large dispersion (Table 1), the injuries observed under flexion mechanisms were less severe as under extension and coupled kinematics. Further investigation, with enlarged impact direction and velocity taking into account for pressure effects could complete this analysis. If fuses areas could be clearly established on the upper and lower cervical spine, enlarge investigation are needed to promote new injury criteria for neck segment. Such investigation could also be followed by significant improvement in model to properly describe fracture processes.

\begin{tabular}{|l|l|l|l|}
\hline Impact & $1^{\text {st }}$ injury & $2^{\text {nd }}$ injury & $3^{\text {rd }}$ injury \\
\hline Frontal & $\begin{array}{l}\text { ALL at C1- } \\
2(12.5 \mathrm{~ms})\end{array}$ & C6 (20ms) & C5 (21ms) \\
\hline Lateral & C6 $(6 \mathrm{~ms})$ & $\begin{array}{l}\text { C1-2 } \\
(9.5 \mathrm{~ms})\end{array}$ & $\begin{array}{l}\text { C5\&CLR\&LF at } \\
\text { C5-6(17ms) }\end{array}$ \\
\hline Rear & $\begin{array}{l}\text { ISL at C1-2 } \\
(4 \mathrm{~ms})\end{array}$ & $\begin{array}{l}\text { PLL } \\
(12 \mathrm{~ms})\end{array}$ & LF atC4-6 (15ms) \\
\hline $\begin{array}{l}\text { Frontal } \\
\text { oblique }\end{array}$ & C6 (6ms) & $\begin{array}{l}\text { C5\&AL } \\
(10 \mathrm{~ms})\end{array}$ & $\begin{array}{l}\text { C4\&AlarLig } \\
(14 \mathrm{~ms})\end{array}$ \\
\hline $\begin{array}{l}\text { Rear } \\
\text { oblique }\end{array}$ & $\begin{array}{l}\text { ISL at C1-2 } \\
(4.5 \mathrm{~ms})\end{array}$ & C5 (14ms) & ISL at C2-3 (17ms) \\
\hline
\end{tabular}

Table1 The injury chronology in five tests

\section{References}

[1] Franckel N., Basic biomechanics of the musculoskeletal system third edition, ISBN 0-683-30247-7

[2] Panjabi MM, Cholewicki J, Nibu K, Babat LB, Dvorak J, Simulation of whiplash trauma using whole cervical spine specimens, Spine, 23(1), 17-24, Jan 1998

[3] Panjabi MM, Cholewicki J, Nibu K, Grauer JN, Babat LB, Dvorak J, Bar HF, Biomechanics of whiplash injury, Orthopade, 27(12), 813-9, December 1998

[4] P. Tropiano, L. Thollon, P. J. Arnoux, K. Kayvantash, C. Brunet, D.G.Poitout, Simulation d'un traumatisme du rachis cervical par impact postérieur (Whiplash) à l'aide du modèle HUMOS, e-mémoires de l'Académie Nationale de Chirurgie, 2003, 2 (1) : 24-30

[5] J. Cholewicki, M.M. Panjabi, K. Nibu, L.B. Babat, J.N. Grauer and J. Dvorak, Head kinematics during in vitro whiplash simulation, Accid Anal Prev 30 (1998), pp. 469-479.

[6] Ito S, Ivancic PC, Panjabi MM, et al. Soft tissue injury threshold during simulated whiplash: a biomechanical investigation. Spine 2004;29(9):979-87

[7] Yoganandan N, Kumaresan S, Pintar FA., Biomechanics of the cervical spine Part 2: Cervical spine soft tissue responses and biomechanical modeling. Clin Biomech (Bristol Avon) 2001 jan;16(1):1-27 